Historia i Polityka

Półrocznik poświęcony myśli politycznej i stosunkom międzynarodowym

$\mathrm{Nr} 9(16) / 201345-57$

DOI: http://dx.doi.org/10.12775/HiP.2013.003

Patryk Tomaszewski (Uniwersytet Mikołaja Kopernika w Toruniu)

\title{
Siły zbrojne w polskiej myśli politycznej od roku 1989 do wyborów parlamentarnych w 2011 r.
}

\author{
Armed forces in the Polish political thought since 1989 \\ till the parliamentary elections in 2011.
}

The author analyses the political thought of Polish political parties after the 1989 concerning the armed forces. From the author's research appears that the military issues discussed in political thought during the period 1989-2011 were primarily in terms of international level. While in matters relating to:

- professionalize of army;

- creating a professional army;

- modernization of the army;

- civilian control over the army;

- were connected with the participation of Polish troops in missions outside the country.

Słowa klucze: Bezpieczeństwo w myśli politycznej, wojsko w myśli politycznej, profesjonalizacja armii, bezpieczeństwo Polski, armia w myśli politycznej, Patryk Tomaszewski, Armed forces in the Polish political thought since 1989

W wydanej w 2009 r. książce Grzegorza Kucharczyka „Polska myśl polityczna po 1989 roku", prawie zupełnie czytelnik nie znajdzie odniesień do spraw związanych $\mathrm{z}$ obronnością. Jeśli zaś pojawiają się jakieś wzmianki, to wyłącznie w aspekcie polityki zagranicznej i polskiego bezpieczeństwa w ramach organizacji międzynarodowych. Również w wydanej w roku 2008 pracy zbiorowej pod redakcją Ewy Maj i Alicji Wójcik, pt.: „Myśl polityczna w Polsce po 1989 roku. Wybrane nurty ideowe”, znaleźć można podrozdziały odnoszące się przede wszystkim, do bezpieczeństwa międzynarodowego Polski ${ }^{1}$, natomiast brak jest w tej pracy wskazań co do spraw związanych z obronnością, czy też węziej z armii. Należy

1 Myśl polityczna w Polsce po 1989 r. Wybrane nurty ideowe, pod red. E. Maj, A. Wójcik, Lublin 2008, ss. 33-34, 57-58, 79, 108, 142, 145, 160, 214, 293-295. 
zatem odpowiedzieć sobie na pytanie, czy kwestie dotyczące armii nie znajdowały odniesień w polskiej refleksji politycznej? Jeśli były poruszane, to czy wyłącznie w aspekcie międzynarodowym? Analiza enuncjacji politycznych, a także publicystyki politycznej, pozwala stwierdzić, iż takie odniesienia były, choć występowały na marginesie, zazwyczaj w kontekście rozważań odnoszących się do polityki zagranicznej lub obronnej Polski. Najwięcej uwag dotyczących kwestii obronności w polskiej myśli politycznej² dotyczyło następujących zagadnień:

- profesjonalizacji i uzawodowienia armii;

- modernizacji armii;

- cywilnej kontroli nad armią;

- udziału polskich żołnierzy w misjach poza granicami kraju.

Dyskusja na temat sił zbrojnych w obecnej myśli politycznej znacznie różni się od tej prowadzonej w latach 1918-1939. Wówczas skomplikowana sytuacja międzynarodowa i wewnętrzna (zarówno jeśli chodzi o zagrożenia integralności państwa, jak i formę sprawowania władzy - czyli udział wojskowych w jej sprawowaniu) powodowała, że tematy związane z armią znajdowały szerokie odniesienie w polskiej myśli politycznej3.

Obecnie rozważania na temat: wojska, obronności i modernizacji armii, stanowić powinny jeden z fundamentów formułowania przez rządzących właściwych strategii i programów dotyczących polskiej armii, a opozycji pozwoliłyby w sposób konstruktywny podejmować polemikę z rządzącymi ${ }^{4}$. Niestety odniesienia do roli wojska w systemie bezpieczeństwa Polski, związane są często z bieżącą praktyką rządzenia (na usługi Ministerstwa Obrony Narodowej i Rządu), rzadziej z przemyślanym dalekosiężnym planem koncepcyjnym.

2 Przez myśl polityczną należy rozumieć: ,,wszelkie wyartykułowane pojęciowo wypowiedzi dotyczące sfery polityki”. Za: A. Zybertowicz, Kategorie do badania polskiej myśli politycznej (rozważania wstępne), [w:] Studia zdziejów polskiej myśli politycznej, t. II, Polska myśl polityczna w dzielnicy pruskiej wXIXw., pod red. S. Kalembki, Toruń 1990, s. 10.

3 J. Zalewski, Apolityczność sił zbrojnych Drugiej i trzeciej Rzeczypospolitej Polskiej. Teoria i praktyka, Warszawa 2009, s. 101-134; J. Figat, Problematyka wojskowa w myśli politycznej Zwiąku Ludowo-Narodowego, Wojskowy Przegląd Historyczny, 1992, nr 4, s. 28-40; T. Sikorski, „Wychowanie żotnierza gotowego do uderzenia". Problematyka wychowania do wojny w publicystyce politycznej Związu Młodej Polski (1937-1939), [w:] Organizacje mtodzieżowe w XX wieku. Struktura, ideologia, dziatalność, red. P. Tomaszewski, M. Wołos, Toruń 2008, s. 164-184; Reasekuracja polskiego interesu narodowego i racji stanu w myśli politycznej II Rzeczypospolitej, red. A. Wojtas, Toruń 1991.

4 Obecnie sporo prac koncepcyjnych odnoszących się do sfery bezpieczeństwa militarnego formułowanych jest przez środowisko naukowców i analityków związane z Prezydentem Bronisławem Komorowskim i Biurem Bezpieczeństwa Narodowego. 
W początkowym okresie transformacji ustrojowej, a więc w latach 1989-1993, dyskurs o siłach zbrojnych dotyczył przede wszystkim aspektów międzynarodowych:

- wycofania się z Układu Warszawskiego - lata 1989-1991;

- wejścia Polski do niezależnego układu politycznego - czyli koncepcja budowania bezpieczeństwa zbiorowego Polski w oparciu o Konferencję Bezpieczeństwa i Współpracy w Europie oraz współpracy z sojuszem wojskowym w postaci Paktu Północnoatlantyckiego;

- wycofania wojsk ZSRR (a później Federacji Rosyjskiej) z terenu Rzeczypospolitej;

- przebudowania doktryny obronnej Polski.

$\mathrm{Na}$ początku lat 90-tych w kształtowaniu polityki obronnej zauważalny był udział ówczesnego Prezydenta Lecha Wałęsy5. Spory między parlamentem a prezydentem w okresie 1991-1995 wykorzystywał w pewnym sensie sztab generalny utrzymujący stosunkowo dużą niezależność od ministra obrony narodowej. Dyskusja polityczna w owym okresie odnosiła się zaś przede wszystkim do zagadnień związanych z cywilna kontrola nad armią oraz relacji między sztabem generalnym a ministrem obrony narodowej. W 1991 roku pierwszym cywilnym ministrem obrony narodowej został powołany przez Jana Olszewskiego - Jan Parys (minister od 23 XII 1991 do 23 V 1992 r.). Podczas kierowania przez niego resortem doszło do zaostrzenia konfliktu związanego z przeniesieniem w stan spoczynku, jego poprzednika wiceadmirała Piotra Kołodziejczaka, co odbyło się bez porozumienia z prezydentem Wałęsą 6 .

Cywilny nadzór nad wojskiem stał się jednak faktem, zaś kolejnym ministrem obrony narodowej został - Janusz Onyszkiewicz. W programach politycznych większości ugrupowań, z lat dziewięćdziesiątych minionego wieku, podkreślano, że najważniejszy dla bezpieczeństwa państwa jest właśnie cywilny nadzór nad wojskiem, a także apolityczność wojska. Onyszkiewicz oceniając, po objęciu teki ministra, podejście sfer wojskowych do apolityczności stwierdzał: „Kadra dosyć prędko przekonała się do apolityczności wojska, albo raczej do apartyjności"7. Cywilny nadzór nad wojskiem stał się więc postulatem i dążeniem liczących się na scenie ugrupowań politycznych i choć od przemian ustrojowych mi-

5 J. Zalewski, Wojsko Polskie w przemianach ustrojowych 1989-2001, Warszawa 2002, s. 158-159; J. Olszewski, Prosto w oczy, Rozmawia Ewa Polak-Pałkiewicz, Warszawa 1997, s. 310-311.

6 A. Dudek, Historia polityczna Polski 1989-2005, Kraków 2007, s. 195; Jan Olszewski, Prosto w oczy, op. cit., s. 310-311.

7 Onyszkiewicz ze szczytów do NATO. Z Januszem Onyszkiewiczem rozmawiaja Witold Bereś i Krzysztof Burnetko, Warszawa 1999, s. 105. 
nęło ponad dwadzieścia lat, jest nadal podkreślany, choćby przez wspomnianego Onyszkiewicza ${ }^{8}$.

W początkowym okresie po 1989 r., politycy i publicyści związani z poszczególnymi nurtami politycznymi podejmowali próby odpowiedzi na pytanie jaka ma być armia - zawodowa czy też poborowa? Pierwszą partią opowiadającą się za całkowitym uzawodowieniem armii była, posiadająca wówczas trzech posłów, konserwatywno-liberalna Unia Polityki Realnej. Inne ugrupowania parlamentarne wspominały raczej o częściowym uzawodowieniu i unowocześnieniu armii, zwracając uwagę na ewolucyjny proces zmian w wojsku. Partia Janusza KorwinaMikke wspominała natomiast o modernizacji, która nastąpić miała dzięki redukcji sił zbrojnych (tym samym obniżeniu kosztów utrzymania wojska). W programie wyborczym z 1993 r. przedstawiciele UPR twierdzili, że należy podnieść wydatki na armię i policję o 50 procent, a armię poborową zastąpić ochotniczą armią zawodową ${ }^{9}$ W 1997 r., działacze związani z Januszem Korwinem-Mikke, startowali wspólnie z innymi małymi ugrupowaniami prawicowymi, działając jako komitet wyborców - Obywatelski Komitet Wyborczy Unia Prawicy Rzeczypospolitej. W programie potwierdzono chęć utworzenia armii w pełni zawodowej: „przyspieszenie unowocześnienia wojska polskiego i utworzenie armii zawodowej oraz formacji obrony terytorialnej opartej na powszechnym i krótkoterminowym szkoleniu wojskowym"10.

W innych środowiskach prawicowych, w początkowym okresie po 1989 r., zaznaczano raczej chęć unowocześnienia armii oraz jej częściowego uzawodowienia. O takiej armii pisano w programie Katolickiego Komitetu Wyborczego „Ojczyzna”, którego filar stanowiło założone w 1989 roku Zjednoczenie Chrześcijańsko-Narodowe oraz mniejsze partie o proweniencji chadeckiej ${ }^{11}$. Niemniej ludowo-chrześcijańska partia Romana Bartoszcze „Ojcowizna” w swym programie z lutego 1992 roku deklarowała: „Uważamy, że stan i struktura naszych sił zbrojnych musi gwarantować bezpieczeństwo państwa. Należy niezwłocznie dokonać reformy i modernizacji naszej armii w kierunku wojska zawodowego właściwie wysokowyspecjalizowanego i dobrze wyposażonego"12. W kolejnych latach również w enuncjacjach partii politycznych, poza nielicznymi wyjątkami, wspomniano raczej o uzawodowieniu, a nie stworzeniu armii zawodowej. Stosunkowo dużo miejsca na temat sił

8 J. Onyszkiewicz, Wojsko, władza, polityka, Polska Zbrojna, nr 40, 2 X 2011, s. 26.

9 Wybory 1993. Partie i ich programy, pod red. I. Słodkowskiej, Warszawa 2001, s. 379.

10 Wybory 1997. Partie i ich programy, pod red. I. Słodkowskiej i M. Dołbakowskiej, Warszawa 2004, s. 205.

11 Wybory 1993. Partie i ich programy, pod red. I. Słodkowskiej, Warszawa 2001, s. 67.

12 Polska Partia „Ojcowizna”, Stużyć zwyktym ludziom i ojczyźnie, b. w, Warszawa 1992, s. 6. 
zbrojnych poświęciła centrowa, powstała z połączenia Unii Demokratycznej oraz Kongresu Liberalno-Demokratycznego - Unia Wolności. W programie tej partii z 1997 r. zapisano jak zdaniem ugrupowania powinno wyglądać Wojsko Polskie:

- apolityczna armia, znajdująca się pod cywilną kontrolą;

- siły zbrojne złożone z wojsk operacyjnych i sił obrony terytorialnej;

- optymalizacja wydatków na modernizację wojska. (Środki na ten cel pochodzić miały z budżetu, a także z racjonalizacji wydatków wojska, jak chociażby wyzbycia się zbędnej infrastruktury);

- działania na rzecz stopniowego uzawodowienia wojska w pierwszym etapie oraz skrócenie służby wojskowej do 12 miesięcy ${ }^{13}$.

Potrzebę unowocześnienia armii, widziała zarówno centroprawicowa koalicja Akcja Wyborcza Solidarność, jak i chłopskie Polskie Stronnictwo Ludowe ${ }^{14}$. Również lewicowi politycy Sojuszu Lewicy Demokratycznej, byli za stopniowym uzawodowieniem armii, skracaniem czasu pełnienia zasadniczej służby wojskowej oraz zwiększaniem efektywności szkolenia wojskowego żołnierzy służby zasadniczej i absolwentów wyższych uczelni ${ }^{15}$. Interesujące jest, iż minister spraw zagranicznych, Włodzimierz Cimoszewicz, choć związany z ugrupowaniem o charakterze lewicowym, a więc z definicji zazwyczaj antymilitarystycznym, cztery lata po przystąpieniu Polski do NATO, pisał, że nie wykluczone są zwiększone wydatki na armię związane z polskim udziałem w Pakcie Północnoatlantyckim. Jednocześnie, choć niestety bardzo ogólnikowo, wspominał o rozszerzeniu i modernizacji sojuszu ${ }^{16}$.

Większość parlamentarnych ugrupowań wraz z modernizacją armii przewidywała jej redukcję przy jednoczesnym rozbudowywaniu obrony terytorialnej. Takiego zdania byli działacze np. Ruchu Odbudowy Polski ${ }^{17}$, czy też były minister obrony narodowej i działacz Ruchu dla Rzeczypospolitej, Romuald Szeremietiew, który opowiadał się za zachowaniem obowiązkowej służby wojskowej oraz obroną terytorialną. Podawał konkretne liczby: ogółem siły operacyjne miały liczyć według niego 80-100 tys. a obrona terytorialna $100-120$ tys. ${ }^{18}$.

Fakt, że refleksja polityczna prowadzona na temat sił zbrojnych, w pierwszych latach po 1989 r. prowadzona była bez udziału analityków wojskowych, a także,

13 Wybory 1997. Partie i ich programy, pod red. I. Słodkowskiej i M. Dołbakowskiej, Warszawa 2004, s. 87-88.

14 Ibidem, ss. 107, 193.

15 Wybory 2001. Partie i ich programy, pod red. I. Słodowskiej, Warszawa 2002, s. 37.

16 W. Cimoszewicz, Polityka zagraniczna Polski - aktualne wyzwania, Warszawa 2003, s. 10-11.

17 Założenia programu odbudowy u przebudowy Polski, (Uchwalone przez V Kongres ROP), http://www.olszewski.pl/idx_rop.htm (dostęp: 25 XII 2012 r.).

18 R. Szeremietiew, Strategia narodowego bezpieczeństwa, Warszawa 2000, s. 90. 
co częściowo zrozumiałe (ze względu na apolityczność) przedstawicieli wojska ${ }^{19}$, spowodowało, że o armii mówiono raczej z punktu widzenia przekonań danych polityków, rzadko zaś z punktu widzenia pogłębionej strategii oraz wizji kierunków rozwoju polskiej armii. Taki stan koncepcji wojskowych we współczesnej polskiej myśli politycznej jest wynikiem braku komplementarnej wiedzy polityków i publicystów politycznych, odnoszących się do oceny zdolności sił zbrojnych w trzech kategoriach opisujących sprawnie działające wojska (zasoby ludzkie, wyposażenie i uzbrojenie oraz organizacja) ${ }^{20}$.

Po roku 2001 nastąpiły zasadnicze zmiany na scenie politycznej, pojawiły się nowe silne podmioty polityczne, częściowo zbudowane na bazie Akcji Wyborczej Solidarność - Platforma Obywatelska oraz Prawo i Sprawiedliwość. Do Sejmu dostali się także reprezentanci partii nie mających wcześniej reprezentacji parlamentarnej: Ligi Polskich Rodzin oraz Samoobrony RP.

Za zachowaniem obowiązku odbywania zasadniczej służby wojskowej opowiadało się PiS. W programie tej partii z 2005 roku czytamy: „PiS będzie dążył do maksymalnego skrócenia czasu trwania obowiązkowej służby wojskowej tak, aby ograniczyć go jedynie do procesu szkolenia poborowego. Powszechnemu obowiązkowi wojskowemu powinni być poddani najlepsi poborowi, podnosząc poziom rezerw i tworząc odpowiednie wzorce postaw społecznych. Będziemy wspierać rozwój atrakcyjnego programu szkolenia wojskowego studentów i programu klas wojskowych w szkołach średnich, razem z odpowiednim systemem zachęt" ${ }^{21}$. Do dziś w środowiskach związanych z Prawem i Sprawiedliwością podnoszone są opinie negatywnie oceniające zawieszenie obowiązku odbywania zasadniczej służby wojskowej.

Obok różnych zarzutów odnoszących się do programu profesjonalizacji armii, zbyt małej liczebności sił zbrojnych, braku odpowiedniego kształtu rozwoju Narodowych Sił Rezerwowych, ciekawy argument zaprezentował w roku 2008 kojarzony z prawicą publicysta Bronisław Wildstein. Na swoim blogu pisał: „Rezygnacja $\mathrm{z}$ armii poborowej to jednak znacznie więcej niż zmiana militarnej doktryny. Pobór powszechny był obok powszechnego szkolnictwa fundamentem budowy współczesnej świadomości narodowej. Mieszkańcy kraju w większości żyjący

19 Jedynym widocznym przykładem działań wojskowego to udział generała Tadeusza Wileckiego, startującego bez sukcesu (niecałe 29 tys. głosów) w wyborach prezydenckich w 2000 roku. Był to jednak kandydat popierany wyłącznie przez środowiska nacjonalistyczne (przede wszystkim Stronnictwo Narodowo-Demokratyczne).

20 M. Kozub, A. Brzozowski, R. Niedźwiecki, Wybrane problemy planowania rozwoju zdolności sit zbrojnych, Wydawnictwo Akademii Obrony Narodowej, Warszawa 2012, s. 52.

${ }^{21}$ IV Rzeczpospolita. Sprawiedliwość dla wszystkich, Program PIS 2005, s. 51-52. 
w swoich małych ojczyznach, w wojsku właśnie zaczynali rozumieć, że przynależą do zbiorowości znaczenie większej. Dziś świadomość wspólnoty narodowej jest powszechna, ale równocześnie słabną integrujące ją kulturowe więzi. Niektórzy uważają, że to postęp, który rozbraja demony nacjonalizmu. Problem w tym, że w miejsce słabnących więzi narodowych nie pojawiają się żadne inne lojalności”22.

Znaczna część partii politycznych dostrzegała już w latach 90-tych XX wieku potrzebę profesjonalizacji armii. Proces ten nieuchronnie związany miał być z ograniczeniem, a docelowo zniesieniu obowiązku odbywania zasadniczej służby wojskowej. Ten postulat znalazł się również w programie Platformy Obywatelskiej, która wygrała wybory w roku $2007^{23}$ i doprowadziło do zawieszenia odbywania zasadniczej służby wojskowej od 2009 roku. Platforma Obywatelska, wychodziła z założenia, że uzawodowienie sił zbrojnych związane jest z ich profesjonalizacją armii w latach 2008-2009. Szczegóły dotyczące tej koncepcji zostały zapisane w „Programie profesjonalizacji Sił Zbrojnych RP na lata 2008-2010”.

Rzadko w programach i deklaracjach politycznych z lat 90-tych XX w. wspominało się o formacji ideowej żołnierzy. W latach osiemdziesiątych XX w. Aleksander Bocheński pisał: „Ucieczka od patriotyzmu poprzez zaniechanie nauczania historii albo poprzez nauczanie antyhistorii w danym kraju doprowadziłaby szybko do opanowania go przez sąsiadów” ${ }^{24}$. Jedno z nielicznych wskazań bezpośrednio odnoszące się do patriotyzmu zawarli w programie działacze lewicowej Krajowej Partii Emerytów i Rencistów, uznający, że odbycie służby wojskowej powinno być traktowane jako spełnienie powinności patriotycznej. Partia ta zwracała uwagę na potrzebę przeciwstawienia się zjawisku „fali” w wojsku, czyli problemowi znęcania się nad poborowymi ${ }^{25}$.

W niektórych środowiskach, szczególnie poza parlamentarnych, związanych z myślą nacjonalistyczną podkreślano możliwość posiadania broni atomowej przez Wojsko Polskie ${ }^{26}$. Ponadto opowiadano się za utrzymaniem armii poborowej.

Wszystkie środowiska polityczne wspominały o modernizacji armii. Zdecydowana większość partii uznawała, że należy rozwijać polski przemysł zbrojeniowy. W programie Sojuszu Lewicy Demokratycznej z 2001 roku pisano, że przemysł obronny powinien opierać się na własnych możliwościach, tam gdzie jest on w sta-

22 B. Wildstein, Zmierzch epoki poborowych, http://blog.rp.pl/wildstein/2008/08/06/zmierzch-epoki-poborowych/ (dostęp: 12 XII 2012 r.).

23 Program PO. Polska zastuguje na cud gospodarczy, Warszawa 2007, s. 83.

24 A. Bocheński, Rozmyślania o polityce polskiej, Warszawa 1988, s. 39-40.

25 Wybory 1997. Partie i ich programy, pod red. I. Słodkowskiej i M. Dołbakowskiej, Warszawa 2004, s. 266.

26 R. Giertych, Kontrrewolucja mtodych, Warszawa 1994, s. 67-68. 
nie zapewnić uzbrojenie nowoczesne, spełniające standardy $\mathrm{NATO}^{27}$. W programie społeczno-gospodarczym Samoobrony RP z roku 2003 pisano: „Samoobrona RP opowiada się za armią silną, nowocześnie uzbrojoną i dobrze wyposażoną. To trudne zadanie w znacznym stopniu urzeczywistnić może i powinien polski przemysł zbrojeniowy. Wyposażenie polskiej armii w nowoczesny i skuteczny na polu walki sprzęt jest zadaniem trudnym i wymagających przez państwo zaangażowania na ten cel znaczących dla wydatków publicznych państwa środków finansowych. Wobec trudnej sytuacji społecznej, wysokiej stopy bezrobocia jest szczególnie istotne aby jak największy procent tych wydatków zasilił polski obszar gospodarczy. Umowy offsetowe powinny być zawierane z myślą o rozwoju polskiej gospodarki i rozwoju polskich zakładów zbrojeniowych" ${ }^{28}$. Potrzeba udziału polskiego przemysłu zbrojeniowego w modernizacji armii była podkreślana także przez polityków liberalnych i prawicowych.

Generalnie znacznie więcej miejsca w dyskursie politycznym poświęcano udziałowi Polski w Sojuszu Północnoatlantyckim, a później również Unii Europejskiej. Partia Konserwatywna, wskazywała już w 1993 roku, iż najważniejsze z punktu widzenia obronności Polski jest przystąpienie do NATO oraz modernizacja armii. Z kolei Partia Chrześcijańskich Demokratów, dodawała aby powstrzymać się od redukcji wydatków na armię ${ }^{29}$. W programach partii lewicowych nie było jednego uniwersalnego konceptu odnoszącego się do polskiej armii. Prawie wszystkie lewicowe ugrupowania istniejące w czasach III RP, od roku 1993 opowiadały się za przystąpieniem do NATO. Jedną z partii będących przeciwko uczestnictwu Polski w Pakcie Północnoatlantyckim była Komunistyczna Partia Polski ${ }^{30}$. Partia ta sprzeciwiała się m. in. dominującej jej zdaniem roli USA w sojuszu. Innego zdania byli działacze Unii Pracy. Pisali oni, że: „polityczna i wojskowa obecność Stanów Zjednoczonych w Europie jest czynnikiem stabilizującym" ${ }^{31}$. Generalnie jednak, większość ugrupowań parlamentarnych opowiadała się za bezpieczeństwem zbiorowym w ramach NATO, UE oraz innych organizacji międzynarodowych, takich jak: ONZ, Organizacja Bezpieczeństwa i Współpracy w Europie ${ }^{32}$.

27 Wybory 2001. Partie i ich programy, pod red. I. Słodowskiej, Warszawa 2002, s. 37.

28 Program społeczno-gospodarczy Samoobrony RP, http://www.samoobrona.org.pl/pages/01. Program/index.php?document=/489.program.html\#11 (dostęp: 12 XII 2012 r.).

29 Wybory 1993. Partie i ich programy, pod red. I. Słodkowskiej, Warszawa 2001, ss. 67, 76.

30 Ł. Tomczak, Lewicowe partie polityczne w Polsce. Programy, organizacja, strategie, Szczecin 2012, s. 175.

31 Za: Ł. Tomczak, op. cit., s. 177.

32 Z. Nowakowski, Bezpieczeństwo państwa w koncepcjach programowych partii parlamentarnych w Polsce po 1989 roku, Warszawa 2009, s. 372-373. 
Do innych wniosków dochodzili w początku lat 90-tych działacze Konfederacji Polski Niepodległej, którzy uznawali, że należy wrócić do stworzenia grupy państw współpracujący ze sobą w ramach tzw. międzymorza. Politycy KPN nawiązywali więc świadomie do koncepcji ukutych w kręgach piłsudczykowskich jeszcze w czasach II RP. Przywódca KPN, Leszek Moczulski, powiedział w sejmie: „Myślę, że głównego zadania dla polityki polskiej nie należy szukać daleko czy bardzo daleko, lecz blisko, a nawet bardzo blisko - główne zadanie dla polityki polskiej leży dokładnie na naszej wschodniej i południowej granicy. W realizacji tego zadania musimy mieć wielu partnerów w obszarze, który się popularnie nazywa międzymorzem. Musimy mieć wielu partnerów, ale z tych wielu partnerów jeden jest dla nas najważniejszy" ${ }^{33}$.

Sporo kontrowersji budził udział polskich wojsk w misjach w Afganistanie i Iraku. Z ugrupowań parlamentarnych w 2001 roku przeciwnikami wysłania Polskich wojsk do tych krajów była Liga Polskich Rodzin i Samoobrona RP. Uznając obie misje, choć szczególnie iracka (która odbyła się bez mandatu ONZ) za agresywne i działające wyłącznie na korzyść USA. Podobne zdanie miały małe ugrupowania lewicowe. Antyklerykalna i radykalna społecznie partia „Racja” uznawała, że należy wypełniać swoje zobowiązania wynikające z uczestnictwa w NATO, ale opowiadała się przeciw udziałowi polskich wojsk w misjach uznawanych za agresywne ${ }^{34}$.

Udział polskich wojsk w misjach w Iraku i Afganistanie był pozytywnie oceniany przez $\mathrm{SLD}^{35}$, PO i $\mathrm{PiS}^{36}$. Z czasem jednak SLD, PO oraz $\mathrm{PSL}^{37}$ zaczęły opowiadać się za wycofaniem polskich wojsk z misji w Iraku, argumentując to posunięcie, brakiem dowodów na posiadanie przez irackie wojsko broni masowego rażenia oraz bezpośrednich powiązań z Al-Kaidą.

Po 2001 roku dyskusja o polskim bezpieczeństwie, weszła w nowy okres, związany z uwypukleniem się globalnych zagrożeń asymetrycznych związanych z terroryzmem. W Polsce zaczęto dyskutować o jeszcze większym zacieśnieniu współpracy strategicznej z USA, egzemplifikację tych poglądów odnajdziemy chociażby w „Strategii Bezpieczeństwa Narodowego Rzeczypospolitej Polskiej”

33 Wystapienie sejmowe Leszka Moczulskiego w dniu 30 kwietnia 1993 roku nt. polityki zagranicznej Polski, [w:] Konfederacja Polski Niepodlegtej a polska polityka zagraniczna. Wybór dokumentów sejmowych, Warszawa 1993, s. 37.

34 Ł. Tomczak, op. cit., s. 177.

35 Ibidem, s. 179.

36 J. Sanecka-Tyczeńska, Państwo obywatelskie i wspólnota polityczna. Studium o myśli politycznej Prawa i Sprawiedliwości, Lublin 2011, s. 247.

37 Razem tworzymy lepsza przyszłość. Narodowe priorytety PSL na lata 2007-2011, Warszawa 2007, s. 10 . 
z 2007 roku, w której zapisano: „Szczególne znaczenie w polskiej polityce bezpieczeństwa zachowują stosunki dwustronne ze Stanami Zjednoczonymi. Polska uznaje, iż mają one strategiczny charakter i będzie zabiegać o dalszy ich rozwój w duchu solidarnego i zrównoważonego partnerstwa. Polska będzie działać na rzecz utrwalania amerykańskiej obecności na kontynencie europejskim, także w wymiarze pozamilitarnym. Rozbudowa wszechstronnej współpracy bilateralnej z głównym sojusznikiem Polski powinna być czynnikiem umacniającym więzi transatlantyckie, pozytywnie wpływającym na kształt i jakość współpracy NATO z Unią Europejską i Stanami Zjednoczonymi" ${ }^{38}$.

W ramach strategicznej współpracy z USA, od czasów rządów Akcji Wyborczej Solidarność, wspominano w środowiskach politycznych zarówno prawicowych, jak i lewicowych o możliwości rozmieszczenia na terytorium Polski elementów amerykańskiego systemu obrony przeciwrakietowej. Konsultacje nabrały tempa za rządów Prawa i Sprawiedliwości ${ }^{39}$. Za ścisłą współpracą z USA, a także rozmieszczeniem na terytorium Polski elementów amerykańskiego systemu przeciwrakietowego opowiadała się właśnie ta partia. Przewodniczący sejmowej komisji spraw zagranicznych, ówczesny poseł PiS - Paweł Zalewski, na łamach „Dziennika” w 2007 r. pisał: „Amerykańska tarcza antyrakietowa chroniłaby Polskę nie tylko przed atakiem terrorystycznym, możliwym w świecie po 11 września. Co znacznie ważniejsze - jej budowa na polskim terytorium zwiększyłaby nasze bezpieczeństwo pod każdym względem. A także dałaby nam nową, bardzo korzystną pozycję geopolityczną" ${ }^{0}$.

Sprawa obrony przeciwrakietowej była negocjowana jeszcze w latach 2007-2009 przez Platformę Obywatelską, jednak rozmowy na skutek działań administracji prezydenta Baracka Obamy - zostały przerwane, a Polsce przedstawiono, zmodyfikowaną i znacznie okrojoną propozycję obrony ${ }^{41}$. Ta decyzja administracji USA korespondowała z polityką wyrażaną przez rząd premiera Donalda Tuska, kierujący główną uwagę na rozwój współpracy z UE.

Przeciwnikami rozmieszczenia elementów tarczy przeciwrakietowej w Polsce od początku rozmów były Liga Polskich Rodzin, Samoobrona RP oraz niektóre ugrupowania lewicowe ${ }^{42}$.

W programie PO z 2007 r. odnotowano potrzebę zmiany w systemu dowodzenia wojskiem - przede wszystkim poprawy funkcjonowania systemów informa-

\footnotetext{
38 Strategii Bezpieczeństwa Narodowego Rzeczypospolitej Polskiej, Warszawa 2007, 13.

39 R. Kuźniar, Polityka zagraniczna III RP, Warszawa 2012, s. 316.

40 P. Zalewski, $Z$ tarczq antyrakietową będziemy bliżej USA, http://wiadomosci.dziennik.pl/ opinie/artykuly/199305,z-tarcza-antyrakietowa-bedziemy-blizej-usa.html (dostęp: 13 I 2013 r.).

41 R. Kuźniar, op. cit., s. 368-369.

42 Ł. Tomczak, op. cit., s. 182-183.
} 
tycznych na wszystkich szczeblach dowodzenia oraz ich wsparcia. Proponowano również wydłużenie aktywności wojskowej żołnierzy. Deklarowano zwiększenie do poziomu powyżej 25 procent udziału wydatków majątkowych w budżecie $\mathrm{MON}^{43}$.

Program PiS różnił się przede wszystkim od programu prezentowanego przez PO, chęcią utrzymania obowiązku odbywania służby wojskowej, a także większą liczebnością wojska - zakładano jego wielkość na poziomie 150 tys. ${ }^{44}$

Przed wyborami parlamentarnymi 2011 r. najbardziej daleko idące były postulaty reorganizacji polskiej armii, głoszone przez Ruchu Palikota. W programie tej partii zapisano m.in.: „Polska - po doświadczeniach drugiej wojny światowej, ale też całej naszej historii - powinna wyzbyć się w polityce zagranicznej jakichkolwiek elementów militarnych. Stop misjom wojskowym. Wiele krajów członkowskich NATO nie bierze udziału w misjach i nie odbija się to niekorzystnie na ich pozycji międzynarodowej. Co więcej, żadne publiczne obietnice dotyczące korzyści z udziału w misjach w Iraku i w Afganistanie nie zostały spełnione - tania ropa z Iraku, inwestycje dla polskich firm przy odbudowie tego kraju, modernizacja polskiej armii, system rakiet Patriot i wiele innych. Jednocześnie rewizji wymaga cała nasza polityka obronna. Wojny przegrywaliśmy i przegramy następne ze względu na ogromną różnicę potencjału pomiędzy Polską a chociażby Rosją. Teraz trzeba myśleć głównie o funkcjach logistycznych i o pomocy dla ludności na wypadek wojny, a nie o kolejnych ofiarach bitew wojennych. Tym, co chroniło Polskę jako wspólnotę, była i będzie kultura. Kulturze jednak nie można stawiać takich zadań. Ona sama je realizuje wówczas, kiedy jest prawdziwie wolna”5.

W roku 2011 partie polityczne, poza wspomnianym Ruchem Palikota, przede wszystkim koncentrowały się na postulatach dotyczących modernizacji armii, zmianie struktury wydatków, a także systemu i struktury dowodzenia oraz awansu żołnierzy.

W Programie PiS podkreślano istnienie potrzeby restrukturyzacji w sztabie Generalnym WP, którego zadania skupiałyby się na planowaniu oraz doradzaniu ministrowi obrony narodowej. Ważnym elementem nowoczesnego wojska jest zwiększenie zaufania obywateli do wojska, a także wychowywania przyszłych pokoleń w przywiązaniu do tradycji wojskowych i patriotycznych ${ }^{46}$.

W programie PO z 2011, zwracano uwagę na potrzebę przebudowy systemu dowodzenia, poprawę systemów informatycznych, umożliwienie awansów korpusowi szeregowych, utrzymanie wydatków majątkowych - idących na moderniza-

43 Program PO. Polska zastuguje na cud gospodarczy, Warszawa 2007, s. 83.

44 Dbamy o Polskę. Dbamy o Polaków, Program PiS z 2007, b.d i m.w, s.16.

45 Program wyborczy Ruchu Palikota. Nowoczesna Polska, „Fakty i Mity”, nr 37, 16-22 IX 2011, s. 8.

46 Nowoczesna, solidarna, bezpieczna Polska. Program Prawa i Sprawiedliwości, Warszawa 2011, s. $228-230$. 
cję armii na poziomie przekraczającym 25 procent budżetu MON ${ }^{47}$. W roku 2011 mocno eksponował zagadnienia związane z obronnością Sojusz Lewicy Demokratycznej. Sojusz uznawał, że proces profesjonalizacji armii przebiegał zbyt szybko, zaś nakłady na modernizację armii w kluczowych dla jej funkcjonowania obszarach nie zostały zrealizowane (samolot szkolno-bojowy, program śmigłowcowy, modernizacji Marynarki Wojennej) ${ }^{48}$.

Postulaty SLD dotyczyły zarówno modernizacji armii, jak i zwiększenia cywilnego nadzoru nad wojskiem, a także zmian w systemie dowodzenia.

W programie SLD zwracano uwagę przede wszystkim na przyjęcie narodowego programu budowy Marynarki Wojennej; stopniowe wygaszanie misji zagranicznych; reorganizację Narodowych Sił Rezerwowych; zadbanie o rozwój kadry - ścieżki awansu. Ponadto wzmocnienie cywilnego pionu w Ministerstwie Obrony Narodowej; wypracowanie systemu kształcenia pracowników cywilnych na rzecz MON i wojska. Nowe zasady i koncepcja pracy Sztabu Generalnego WP; opracowanie sprawnego systemu dowodzenia; odbiurokratyzowanie i przyśpieszenie procesu informatyzacji resortu obrony narodowej ${ }^{49}$. Okazało się, że przed wyborami w roku 2011, to Sojusz Lewicy Demokratycznej przedstawił najbardziej komplementarny program dotyczący sił zbrojnych. W 2011 r. niewiele w sprawach obronności wypowiadało się Polskie Stronnictwo Ludowe, które zwracało uwagę na potrzebę utrzymania dotychczasowego kadrowego stanu armii, przy jednoczesnym dokończeniu procesu jej profesjonalizacji. Działacze ludowi widzieli potrzebę intensyfikacji szkoleń wojskowych, a także „unormowanie sytuacji w zakresie wynagrodzeń i emerytur wojskowych, tak aby przeciwdziałać odchodzeniu z wojska młodych i wyszkolonych kadr" ${ }^{50}$.

Pewne elementy wspólne znajdowały się zarówno w koncepcjach PiS, PO, PSL jak i SLD. Wszystkie te partie stały na stanowisku utrzymania wydatków na obronność na minimalnym poziomie 1,95 procent $\mathrm{PKB}^{51}$.

47 Następny krok. Razem. Program wyborczy PO 2011, b. m i d. w., s. 83-84.

48 Sojusz Lewicy Demokratycznej. Jutro Bez obaw. Program dla Polski, b. m i d. w., s. 44.

49 Ibidem, s. 49-51.

50 Program PSL 2011, s. 20-21. http://www.psl.org.pl/upload/pdf/Program_Wyborczy_PSL_ 260811.pdf (dostęp: 12 I 2013 r.).

51 Wielkość 1,95 procent PKB na obronność ma swoje umocowanie prawne w „Ustawie z dn. 25 maja 2001 r. o przebudowie i modernizacji technicznej oraz finansowaniu Sił Zbrojnych RP”. Art. 7 ust. 1 niniejszej ustawy wprost wynika, iż na finansowanie potrzeb obronnych RP przeznacza się corocznie wydatki z budżetu państwa w wysokości nie niższej niż 1,95 procent PKB z roku poprzedniego. Warto zwrócić uwagę, że ustawa ta przyjęta została ponad partyjnymi podziałami. Również Sojusz Północnoatlantycki zalecał ustalenie wydatków obronnych na poziomie bliskim 2 procent. 
Od momentu transformacji ustrojowej pewne propozycje dotyczące systemu obronności modelu sił zbrojnych budziły kontrowersje w różnych środowiskach politycznych. Najistotniejszy konsensus dotyczył wejścia Polski do NATO. Sprawa ta nie budziła kontrowersji, nie licząc pozaparlamentarnych ugrupowań nacjonalistycznych, anarchistycznych i pacyfistycznych.

Pogląd na sprawę liczebności polskiej armii zmieniał się wraz z upływem lat. Wszystkie siły polityczne uznawały, że armia z czasów Układu Warszawskiego była zbyt liczna. Kontrowersje jednak budzi faktyczna skali redukcji armii, która wyniosła w Polsce 75 procent (między rokiem 1991 a 2010) i była największą pośród krajów sąsiadujących (poza Szwecją i Czechami) ${ }^{52}$. Poza tym nie było zgody w koncepcjach poszczególnych partii, co do liczebności wojsk operacyjnych oraz obrony terytorialnej. Sporo kontrowersji budziła modernizacja armii, która zdaniem wielu środowisk politycznych przebiegała zbyt opieszale i bez konkretnego dalekosiężnego planu. Często podkreślano bardzo złą strukturę wydatków w armii, a także fatalną kondycję polskiej marynarki wojennej. A także wskazywano na kupowanie sprzętu używanego, wymagającego modernizacji, jak chociażby czołgi Leopard ${ }^{53}$. W niektórych środowiskach wspominano również, że polska armia zbyt dużą wagę przykłada do przygotowania operacyjnego wojska do misji ekspedycyjnych, nie zwracając takiej uwagi na obronę kraju, gdzie w razie konfliktu doszłoby do klasycznej operacji lądowej z wykorzystaniem piechoty i czołgów bardzo już dziś przestarzałych ${ }^{54}$.

W polskiej myśli politycznej najważniejszym wyzwaniem na najbliższe lata będzie odpowiedzenie na pytanie jakie jest miejsce Polski w kształtowaniu nowej strategii Sojuszu Północnoatlantyckiego; podobnie w przypadku utworzenia europejskich sił zbrojnych, a także udziału polskich wojsk w misjach pokojowych i stabilizacyjnych. Ponadto istotne wydaje się opracowanie koncepcji działań budowy zaufania do wojska oraz wspieranie środowisk cywilnych współdziałających $\mathrm{z}$ armią, jak choćby różnego rodzaju stowarzyszenia, a przede wszystkim think tanki działające na rzecz obronności kraju.

52 P. Żurawski vel Grajewski, Bezpieczeństwo międzynarodowe. Wymiar militarny, Warszawa 2012, s. 472.

53 M. Łangalis, Skansen NATO, „Najwyższy Czas”, nr 11, 12 III 2011, s. 7-9.

54 G. Kwaśniak, System (nie)bezpieczeństwa narodowego, Rzeczy Wspólne, nr 2, 2010, s. 86-87. 